\title{
STRUCTURE OF ANT ASSEMBLAGES IN PLANTED POPLAR (POPULUS ALBA) FORESTS AND THE EFFECT OF THE COMMON MILKWEED (ASCLEPIAS SYRIACA)
}

\author{
Anna Ágnes Somogyi ${ }^{1,2}$, GÁbor LốRInczi ${ }^{2}$, Judit Kovács² and István Elek MaÁK ${ }^{2,3}$ \\ ${ }^{1} M T A-D E$ „Lendület” Behavioural Ecology Research Group \\ Department of Evolutionary Zoology, University of Debrecen \\ H-4032 Debrecen, Egyetem tér 1, Hungary; E-mail: panka.somogyi@gmail.com \\ ${ }^{2}$ Department of Ecology, University of Szeged, H-6726 Szeged, Közép fasor 52, Hungary \\ E-mail:lorinczig@gmail.com \\ ${ }^{3}$ Museum and Institute of Zoology, Polish Academy of Sciences \\ Wilcza street 64,Warsaw, Poland; E-mail:bikmakk@gmail.com
}

Besides changes in vegetation during succession, the regular disturbance can be also responsible for the alteration of arthropod assemblages in planted forests, especially when the disturbance allows the establishment of non-native plant species. In our study, we investigated the structure of ant assemblages in plantations of different aged poplar forests (Populus alba) infested with the invasive common milkweed (Asclepias syriaca). Our results showed that the dispersion pattern of colonies was mostly regular with higher interspecific neighbour distances in the younger forests and higher intraspecific neighbour distances in the older forests. In the younger forests, most colonies nested in milkweed stems, while in the older forests colonies used more types of nesting sites and were mostly found in the soil and litter. These findings suggest that depending on whether suitable sites for nesting are limited or not, the importance of intra- and interspecific competition may vary among the different aged forests. The high abundances of milkweed thus can lead to the significant alteration of local ant assemblages, especially in the earlier successional stages of the forests.

Keywords: dispersion pattern, inter-nest distances, invasive species, plantation, succession.

\section{INTRODUCTION}

Poplar forests (with Populus alba and its natural hybrid Populus canescens) are common types of planted forests on calcareous sandy sites in the Danube-Tisza region of Hungary (RÉDEI 2000). In the absence of natural forests, planted forests can still act as shelters for some forest dwelling species (CARNus et al. 2006, Brockerhoff et al. 2008, Bremer \& FArley 2010). For example, the endangered ground beetle, Holcaspis brevicula, a locally endemic species in New Zealand, is thought to depend on a forest plantation, as its only remaining habitat (Brockerhoff et al. 2005). However, the management in planted forests can be much more intense (e.g. intensive logging) than in natural regenerative forests (Noble \& Dirzo 1997). This regular disturbance allows the establishment of non-native species (e.g. plants) (Gordon 1998, Gallé et al. 
2015, GALLÉ et al. 2016), which can induce negative changes in ground-dwelling arthropod assemblages (SCHIRMEL et al. 2011, GALLÉ et al. 2015), usually by altering habitat structure (Hejda et al. 2009). Other consequences of habitat disturbance can be the reduction in the number of habitat specialists (OKLAND et al. 2003), or increase in the number of generalist or open habitat specialist species (RILEY \& Browne 2011, Gallé et al. 2016). In the older planted forests, however, native forest species can settle due to the well-developed soil layer and associated fungal flora, and the increased dead wood on the forest floor (BROCKERHOFf et al. 2008).

Another factor responsible for the alteration of arthropod assemblages is the on-going change of forest vegetation throughout the succession (GALLÉ et al. 2016). From the ants' perspective, forests can differ markedly in many characteristics (e.g. vegetation structure, litter coverage, number of fallen twigs and rotten trunks), which can substantially alter local ant assemblages (GALLÉ et al. 1998, Alvarado et al. 2000, Holec et al. 2006). Therefore, the alteration of these characteristics may lead to changes in the relative and absolute frequencies of different ant species (GAllé 1991), influencing also their foraging behaviour, dispersion, colonising potential and competitive interactions (Puntilla \& Haila 1996, VepsäläInen et al. 2000). Competition is usually considered to have a great effect in shaping ant communities (SAVOLAINEN \& VEPSÄLÄINEN 1988, BRASCHLER \& BAUR 2003), although other types of interactions can also be important, e.g. predation or social parasitism (СzесноwsкI \& Markó 2005, Cerdá et al. 2013, Gallé et al. 2016). The heterogeneity of a given habitat, however, can favour the co-occurrence of several ant species on the same location by decreasing the overlap in resource requirements (CoElHo \& Riberio 2006) and/or by increasing the amount of available nesting sites (BROCKERHOFf et al. 2008).

Ants represent a diverse and locally very abundant group of omnivorous forest arthropods (HöLldobler \& Wilson 1990). Since they are keystone species in several ecological processes that can be sensitive to environmental changes, they can provide substantial information about the ecological and functional implications of disturbances (Hoffman \& Andersen 2003, Ribas et al. 2012). The quality of a given habitat is determined primarily by the variability and quantity of available nesting sites and food resources (BRASCHLER \& BAUR 2003), but it can also be influenced by the presence of other ant species, especially by those with similar needs (Levings \& Traniello 1981, Andersen 1991, Davidson 1998).

In our study, we investigated the structure and composition of ant assemblages in plantations of different aged poplar forests infested with the invasive common milkweed (Asclepias syriaca) by using nest mapping. We expected that there would be differences (1) in the dispersion pattern and internest distances of colonies, (2) in the types of nesting sites and proportion of 
each nesting site used, and (3) in the influence of the milkweed cover on the nesting habits of ants among the different aged forest stands.

\section{MATERIAL AND METHODS}

Study site - Our field work was carried out near Bugacpusztaháza village (in the southern Great Plain region of Hungary) in June 2012. This region has a characteristic semidesert climate, therefore, local plant assemblages usually develop on large granulous sandy soil (KERTÉsz et al. 2011), but a chernozem or a chernozem-like sandy soil is also present in several parts of the region (Biró 2006). The mean annual precipitation is between 550-600 $\mathrm{mm}$, and the mean temperature varies between $10.2^{\circ} \mathrm{C}$ and $10.8^{\circ} \mathrm{C}$ (Тӧвӧк et al. 2003).

We investigated four mixed deciduous forest stands, which were mainly formed by P. alba (at least $70 \%$ ), with at least 10 years between their age. For nest mapping, we choose a 10-year-old (ca. 11 ha, further FA), a 26-year-old (ca. 3.2 ha, further FB), a 36-year-old (ca. 5 ha, further FC), and a 46-year-old (ca. 3.35 ha, further FD) forest. The smallest distance between the forests was $800 \mathrm{~m}$.

Asclepias syriaca, the common milkweed is a native to the eastern part of North America (BHowmik \& BAden 1976), but it is considered an invasive species in Hungary. The species was repeatedly introduced to Hungary over the past few centuries, and as a successful invader, it has recently spread rapidly, especially on sandy soils, infesting forest plantations, field crops, vineyards, orchards and other habitats under anthropogenic influence (BALOGH et al. 2007, BAGI 2008). According to the study of GAllé et al. (2015), the common milkweed has mixed (i.e. negative but also positive) effects on local invertebrate assemblages. Aphids that feed on common milkweed are usually tended by ants for their honeydew (Smith et al. 2008, Molnár et al. 2010, Abdala-Roberts et al. 2012, Gallé et al.

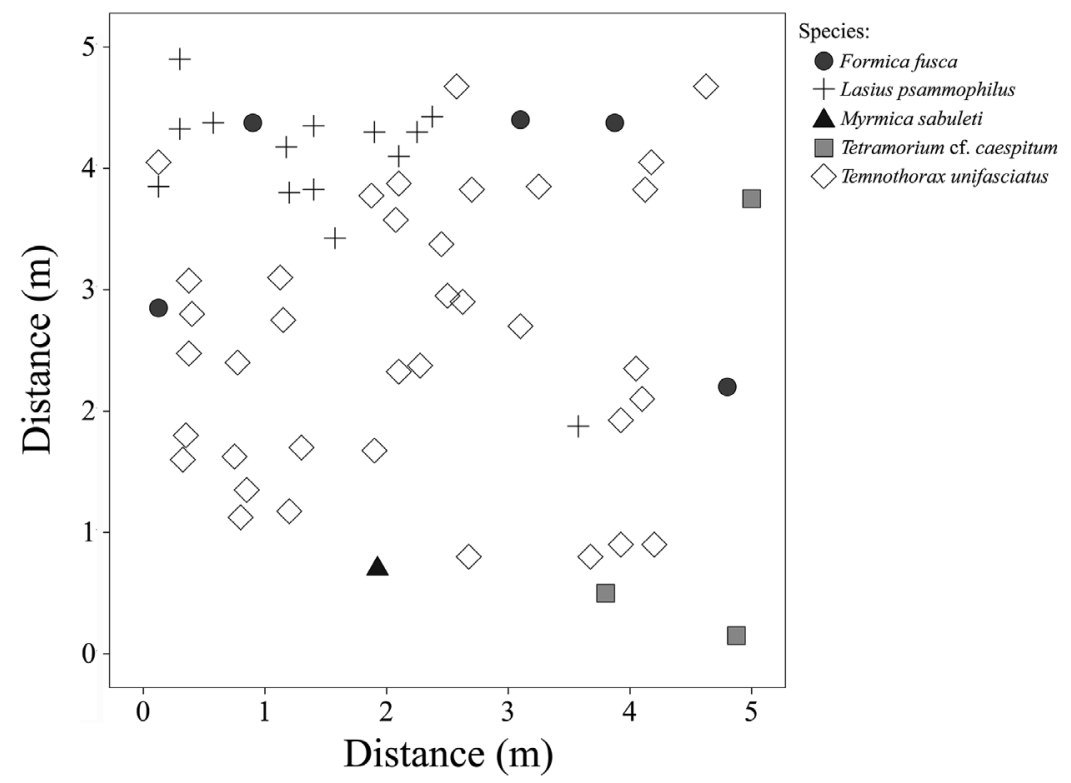

Fig. 1. An example of $5 \mathrm{~m} \times 5 \mathrm{~m}$ sampling plot (FB1) from the 26-year-old forest (FB) 


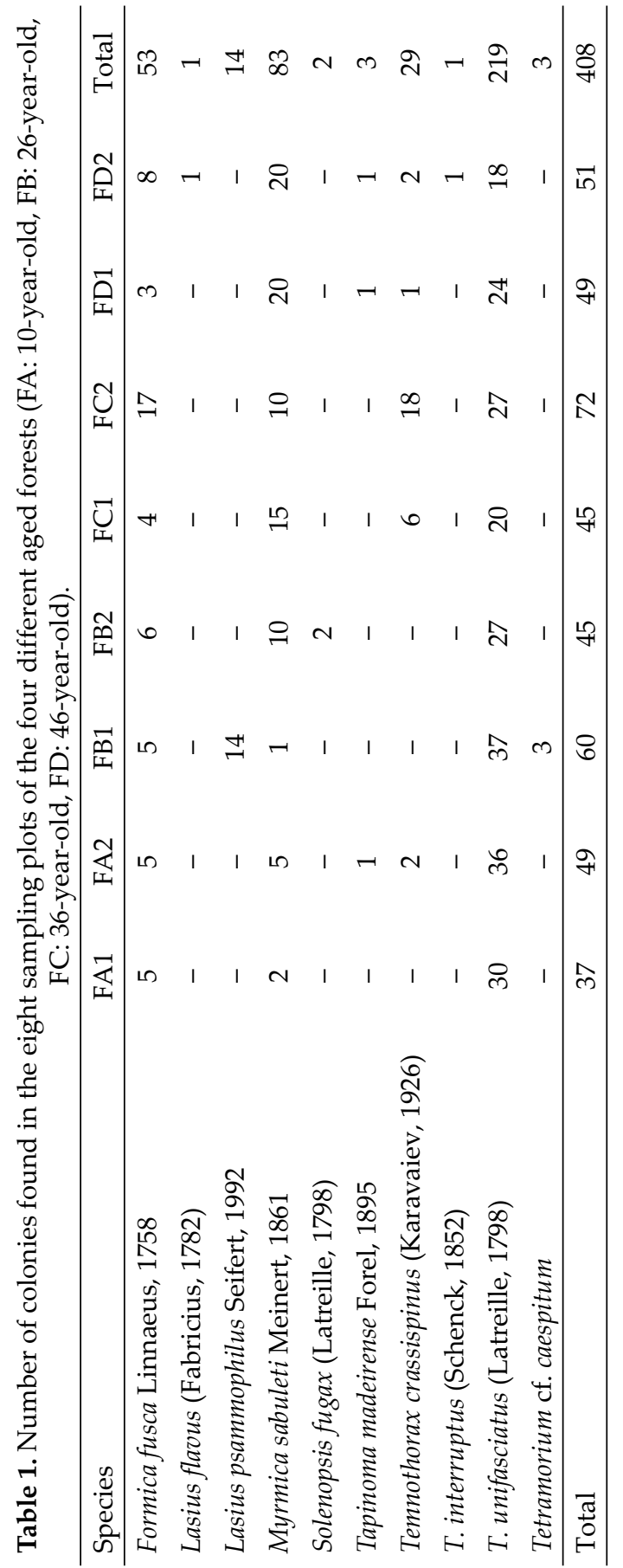

2015), and hollow milkweed stems can serve as potential nesting sites for many ant species (Alloway 1979, StUART 1992).

Study methods - In order to survey local ant assemblages, we selected two $5 \mathrm{~m} \times 5 \mathrm{~m}$ plots with at least $50 \mathrm{~m}$ distance between them in each forest type. In each plot we surveyed the upper soil surface, leaf litter, snail shells, fallen twigs and stems serving as potential nesting sites for ants. We recorded only those nesting sites that were actually used by an ant colony. To determine the exact distance between individual colonies, the nesting sites were accurately mapped with the help of a grid of $0.2 \mathrm{~m} \times 0.2 \mathrm{~m}$. Together with colony mapping, the type of nesting sites (i.e. in the soil, twigs, etc.) was also recorded. For species identification, we took a sample of at least three workers from each nest. Ants were determined using the keys of Czechowsкi et al. (2002, 2012). In each forest site, the cover of milkweed was estimated in three $1 \mathrm{~m} \times 1 \mathrm{~m}$ plots within a few meters distance from the $5 \mathrm{~m} \times 5 \mathrm{~m}$ plots. In each case, the average of the cover estimates was calculated for the analyses.

Statistical analysis. Dispersion pattern and inter-nest distances of colonies - Using the maps with the coordinates of ant colonies (Fig. 1) we estimated both the dispersion pattern of colonies and their nearest intraspecific and interspecific neighbour distances (further intraspecific distances and interspecific distances, respectively).

The dispersion pattern of colonies was determined using C Cark and Evans' (1954) nearest neighbour method. This was carried out both for all colonies mapped in a 
given sampling plot and for individual species if the number of their colonies was at least 9 per plot. The differences among the different aged forests regarding the intraspecific $(\mathrm{N}=$ 398) and interspecific $(\mathrm{N}=405)$ distances were analysed with GLMMs. In the model, the forest age was included as a fixed factor, while plot ID as a random factor. Since the data was overdispersed, negative binomial error term was used in the model. GLMMs were performed using the glmer function from the lme4 package (BATEs et al. 2015). The relevel function was used to carry out post hoc sequential comparisons among factor levels. We applied a table-wide sequential Bonferroni-Holm correction to reveal the exact significance levels. The within-forest type comparisons of the intraspecific and interspecific distances of colonies were compared with paired Wilcoxon signed rank tests. These pairwise comparisons were also carried out separately for species with 9 or more colonies per plot (as in the analysis of dispersion patterns).

Types of nesting sites and the effect of milkweed - The differences between the older (FC and FD) and younger (FA and FB) forests regarding the number of colonies found in milkweed stems and in other nesting sites were analysed using Fisher's exact tests for count data. This was also carried out separately for Temnothorax unifasciatus, since this species was the only one that was found in each sampling plot. The same statistical analysis was used to test whether there are differences in the relative frequencies of different nesting types and milkweed nests among the different aged forest stands. Relative frequencies of the different types of nesting sites in the different aged forest stands were calculated by dividing the number of colonies occupying that type of nesting site with the total number of colonies mapped.

The correlation between the age of forest stands and the total number of colonies (with and without taking into account the nests in milkweed stems) found inside the stands was calculated with Spearman rank correlation. The same test was used for analysing the relation between the estimates of milkweed cover and the number of nests in milkweed stems from the different aged forests. In these tests, the average of the two plots per forest stand was used.

All statistical analyses were carried out using $R$ statistical environment ( $R$ Development Core Team 2014).

\section{RESULTS}

Altogether, a total of 408 colonies belonging to 10 ant species were found in the eight sampling plots (Table 1). Three species, Formica fusca, Myrmica sabuleti and T. unifasciatus were those that occurred in all plots, while other species were found only in one or a few plots. Overall, more than half of the colonies mapped belonged to T. unifasciatus (FA: 77\% of all colonies, FB: 60.5\%, FC: 48 \% FD: 40\%), which nested mainly in milkweed stems.

\section{Dispersion pattern and inter-nest distances of colonies}

Overall, a total of 12 different types of nesting sites were recorded and distinguished during nest mapping (Table 2). In most cases, the dispersion pattern of colonies was regular, although the colonies of the most frequent 
Table 2. Relative frequencies of nesting site types in the four different aged forests (FA: 10-year-old, FB: 26-year-old, FC: 36-year-old, FD: 46-year-old). Relative frequencies over 0.10 are highlighted in bold.

\begin{tabular}{lcccc}
\hline Nesting site & FA & FB & FC & FD \\
\hline soil & $\mathbf{0 . 1 5}$ & $\mathbf{0 . 2 1}$ & $\mathbf{0 . 2 5}$ & $\mathbf{0 . 4 0}$ \\
soil \& leaf litter & 0.01 & 0.00 & 0.03 & 0.03 \\
soil \& twig & 0.00 & 0.02 & 0.04 & 0.04 \\
soil \& milkweed stem & 0.01 & 0.00 & 0.00 & 0.00 \\
snail house & 0.00 & 0.00 & 0.03 & 0.02 \\
milkweed stem & $\mathbf{0 . 8 0}$ & $\mathbf{0 . 7 1}$ & $\mathbf{0 . 5 0}$ & $\mathbf{0 . 3 5}$ \\
twig & 0.00 & 0.02 & 0.06 & 0.03 \\
leaf litter & 0.02 & 0.01 & 0.05 & 0.11 \\
under stone & 0.00 & 0.02 & 0.03 & 0.00 \\
soil \& under stone & 0.00 & 0.00 & 0.09 & 0.00 \\
litter \& twig & 0.00 & 0.00 & 0.00 & 0.10 \\
soil \& moss & 0.00 & 0.00 & 0.00 & 0.02 \\
\hline
\end{tabular}

species, T. unifasciatus showed all three types of dispersion patterns (Table 3). The dispersion pattern of the colonies of $M$. sabuleti, the second most frequent species, also proved to be mostly regular $(R \geq 1.44, p<0.01)$, except in one of the FC plots, where it exhibited a random dispersion pattern $(\mathrm{R}=0.82, N S)$. The colonies of Lasius psammophilus were present in higher numbers only in one of the FB plots, where they showed an aggregated dispersion $(\mathrm{R}=0.73$, $\mathrm{p}<0.05)$. The colonies of F. fusca and Temnothorax crassispinus, which were found in higher numbers only in the FC2 plot, were also regularly dispersed ( $\mathrm{R}=1.56, \mathrm{p}<0.001$, and $\mathrm{R}=1.49, \mathrm{p}<0.001$, respectively).

When comparing the age categories of forest stands, we found no significant differences among them concerning the intraspecific distances (GLMM $2.1>\mathrm{z}>-1.16, \mathrm{~N}=398, N S)$. There were, however, significant differences between the younger (FA and FB) and older forests (FC and FD) in respect of interspecific distances (GLMM z $=-3.62, \mathrm{~N}=405, \mathrm{p}<0.001$ ), while the differences between the two younger (FA vs FB) and the two older forests (FC vs FD) were not significant $(\mathrm{z}=-0.09, N S$ and $\mathrm{z}=1.09, N S$, respectively).

In the older forests (FC and FD), the intraspecific distances were significantly higher than the interspecific distances (paired Wilcoxon $\mathrm{z}=-6.70$, $p<0.001$ and $z=-5.78, p<0.001$, respectively), while in the younger forests (FA and FB) the opposite pattern was found $(\mathrm{z}=-2.24, \mathrm{p}<0.05$ and $\mathrm{z}=-1.99$, $\mathrm{p}<0.05$, respectively) (Fig. 2). From among species, only T. unifasciatus had enough (9 or more) colonies in each plot to compare the intraspecific and in- 
Table 3. Density and dispersion pattern of all colonies summed and the colonies of the most frequent species in the sampling plots of the different aged forests (FA $=10$-yearold, FB = 26-year-old, FC = 36-year-old, FD = 46-year-old). $\mathrm{N}=$ number of colonies per plot, $\mathrm{R}=$ CLARK and Evans' (1954) dispersion index.

\begin{tabular}{|c|c|c|c|c|c|}
\hline Plot & Species & $\mathrm{N}$ & Density (colony $/ \mathrm{m}^{2}$ ) & $\mathrm{R}$ & Dispersion pattern \\
\hline \multirow[t]{2}{*}{ FA1 } & T. unifasciatus & 30 & 1.20 & $1.28^{* *}$ & regular \\
\hline & all colonies & 37 & 1.48 & $1.18^{* *}$ & regular \\
\hline \multirow[t]{2}{*}{ FA2 } & T. unifasciatus & 36 & 1.44 & $0.79 *$ & aggregated \\
\hline & all colonies & 49 & 1.96 & $1.28^{* * *}$ & regular \\
\hline \multirow[t]{2}{*}{ FB1 } & T. unifasciatus & 37 & 1.48 & $0.91 \mathrm{NS}$ & random \\
\hline & all colonies & 60 & 2.40 & $1.41^{* * *}$ & regular \\
\hline \multirow[t]{3}{*}{ FB2 } & T. unifasciatus & 27 & 1.10 & $1.08 \mathrm{NS}$ & random \\
\hline & M. sabuleti & 10 & 0.40 & $1.71^{* * *}$ & regular \\
\hline & all colonies & 45 & 1.80 & $1.20^{* *}$ & regular \\
\hline \multirow[t]{3}{*}{$\mathrm{FC} 1$} & T. unifasciatus & 20 & 0.80 & $1.40^{* * *}$ & regular \\
\hline & M. sabuleti & 15 & 0.60 & $1.61^{* * *}$ & regular \\
\hline & all colonies & 46 & 1.80 & $1.33^{* * *}$ & regular \\
\hline \multirow[t]{3}{*}{$\mathrm{FC} 2$} & T. unifasciatus & 27 & 1.08 & $1.58^{* * *}$ & regular \\
\hline & M. sabuleti & 9 & 0.36 & $0.82 \mathrm{NS}$ & random \\
\hline & all colonies & 71 & 2.80 & $1.15^{* *}$ & regular \\
\hline \multirow[t]{3}{*}{ FD1 } & T. unifasciatus & 25 & 0.96 & $0.92 \mathrm{NS}$ & random \\
\hline & M. sabuleti & 20 & 0.80 & $1.44^{* * *}$ & regular \\
\hline & all colonies & 50 & 1.96 & $1.19^{* *}$ & regular \\
\hline \multirow[t]{3}{*}{ FD2 } & T. unifasciatus & 19 & 0.76 & $1.27^{*}$ & regular \\
\hline & M. sabuleti & 20 & 0.80 & $1.40^{* * *}$ & regular \\
\hline & all colonies & 52 & 2.40 & $1.05 \mathrm{NS}$ & random \\
\hline
\end{tabular}

t-test: NS $0.05<\mathrm{p}^{*} 0.01<\mathrm{p}<0.05 ;{ }^{* *} 0.001<\mathrm{p}<0.01 ;{ }^{* * *} \mathrm{p}<0.001$

terspecific distances of its colonies. In the younger forests (FA and FB), the interspecific distances (paired Wilcoxon $\mathrm{z}=-4.98, \mathrm{p}<0.001$ and $\mathrm{z}=-4.51$, $\mathrm{p}<0.001$, respectively), while in the older forests (FC and FD) the intraspecific distances were significantly higher $(\mathrm{z}=-2.10, \mathrm{p}<0.05$ and $\mathrm{z}=-2.04, \mathrm{p}<0.05$, respectively).

\section{Types of nesting sites and the effect of milkweed}

In the two younger forests (FA and FB), colonies found in milkweed stems belonged to seven species (F. fusca, L. psammophilus, M. sabuleti, Tapinoma 
madeirense, T. crassispinus, Temnothorax interruptus, T. unifasciatus), while in the two older forests (FC and FD) only the colonies of T. unifasciatus occupied these nesting sites. In each forest type, significantly more colonies of T. unifasciatus were found in milkweed stems than in any other types of nesting sites summed (Fisher exact test, $\mathrm{p}<0.01$ ). In the older forests, the total number of colonies of other species in milkweed stems was significantly lower than that of colonies in other types of nesting sites (Fisher exact test, $p<0.01$ ), while in the younger forests the difference was not significant (Fisher exact test, $\mathrm{p}=0.08$ ).

Ants used slightly more types of nesting sites in the older forests than in the younger ones (FA: 5, FB: 6, FC: 7, FD: 9). With the growing age of the forests, the relative frequencies of colonies in milkweed stems decreased, while the relative frequencies of other types of nesting sites increased (FA: 5:1, FB: 7:2, FC: 2:1, FD: 1:1). From among all nesting sites, three (soil, leaf litter and milkweed stems) were used by ants in all forest stands (Table 2).

The mean cover of milkweed was $36 \%$ in FA, $13 \%$ in FB, $5 \%$ in FC and $9 \%$ in FD. The percent of milkweed cover was significantly correlated with the total number of colonies found in milkweed stems (Spearman rho $=0.85$, $p=0.01)$. There was, however, no significant correlation between the age of forests and the total number of colonies per forest type (Spearman rho $=0.49$, $\mathrm{p}=0.21$ ), although, if colonies in milkweed stems were not taken into account, the correlation became significant (Spearman rho $=0.92, \mathrm{p}<0.001$ ).

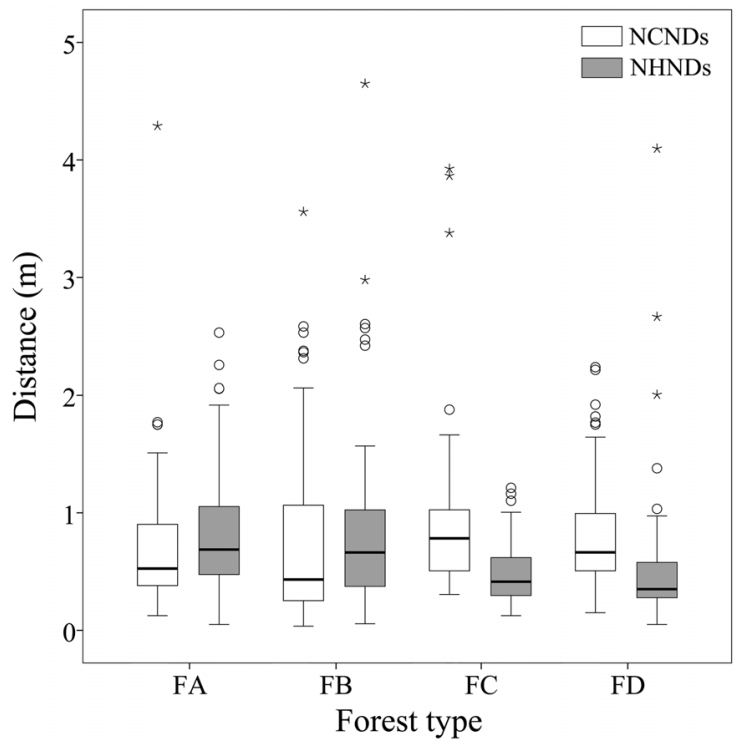

Fig. 2. The nearest intraspecific (white boxes) and interspecific neighbour distances (grey boxes) in the four different aged forests: FA: 10-year-old, FB: 26-year-old, FC: 36-year-old, FD: 46-year-old (median, quartiles, minimum and maximum values, outliers) 


\section{DISCUSSION}

\section{Dispersion pattern and inter-nest distances of colonies}

According to the nearest neighbour method, the dispersion pattern of all colonies found in a given sampling plot was mostly regular, which suggests that competition has an important effect in shaping ant communities in these planted poplar forests. This result is in concordance with many previous findings obtained in other forest habitats (e.g. Levings \& Traniello 1981, Ryti \& Case 1986, Gotelli \& Ellison 2002, Czechowski \& Markó 2005), even if other factors, such as forest age, can mask the overall effect of competition (GALLÉ et al. 2016). Competition can have a significant influence on the dispersion of colonies by shifting them to a more regular (overdispersed) spatial arrangement (Herbers 1989, SoAres \& Schoereder 2001), but it can also cause the exclusion of some species from optimal habitats, forcing them to live under suboptimal conditions (Savalainen \& Vepsäläinen 1988, Andersen \& Patel 1994, Cerdá et al. 1997, SANDERs \& Gordon 2000). In our study, the colonies of individual species also showed a regular dispersion pattern in most cases, indicating the existence of strong intraspecific competition. Regular dispersion seems to be typical when the density of colonies is high, and as a result, the overlap in foraging areas and territories can be reduced (Levings \& TrANielLo 1981, Ryti \& Case 1984, 1986, Cushman et al. 1988). Contrary to these, the colonies of L. psammophilus were aggregated in the FB1 plots, which can be the result of polydomy (i.e. when a colony occupies several nesting sites), as was observed in other Lasius species (Brian et al. 1965, Traniello \& Levings 1986, LóRINCZI 2011). The aggregation of colonies may be not only the result of polydomy, but also of various interspecific interactions (e.g. mutualism) or habitat heterogeneity (Ryti \& Case 1984, Herbers 1989, Soares \& Schoereder 2001).

Based on our results it seems that the types of nesting sites used were mostly determined by interspecific competition in the younger forests. In these habitats, suitable nesting sites seem to be limited, which was also demonstrated by the nesting of most colonies in milkweed stems. On the contrary, more suitable nesting sites were available in the older forests, so the dispersion pattern of colonies may have been determined mostly by intraspecific competition. This was also supported by the comparison of the nearest intraand interspecific neighbour distances.

\section{Types of nesting sites and the effect of milkweed}

During succession, changes in plant diversity are accompanied by changes in habitat variables and by an increase in structural diversity, which can promote the settlement of newcomer ant species and the coexistence of 
resident ones (Doncaster 1981, Coelho \& Riberio 2006). One can expect that ant species richness will increase during succession in response to an increase in structural diversity and forest age (GALlé et al. 2016), but this is not always the case. For instance, Osorio-Perez et al. (2007) found that the 25-35 years old Puerto Rican forests had the highest ant species richness, since these forests combine the advantageous properties of both the younger ( $0-5$ years) and older (over 60 years) forests.

Early colonizing (pioneer) species have lesser habitat requirements, so they can colonise at the beginning of forest formation, but since they are weaker competitors and react more sensitively to the changes of microclimatic properties, they get easily excluded under stronger competitive pressure (Connell \& Slatyer 1977, Soares 2013). On the other hand, poplar forests do not form a closed canopy; moreover, an older forest can even open up (BorHIDi 2003), so the appearance of species that are early colonisers, or occur on open, sandy habitats (e.g. Tetramorium cf. caespitum or L. psammophilus) is not surprising, which is supported also by our results. Furthermore, the presence of these species in the younger forest can be explained by the fact that there are still opened sandy patches on the forest floor (GALLÉ 1991).

Our results indicate that milkweed cover has a significant influence on the nesting habits of some ant species. In the younger forests, where potential nesting sites were scarce, several species and not just typical cavity-dwellers made their nests in milkweed stems, such as T. crassispinus, T. interruptus, $L$. psammophilus, M. sabuleti and F. fusca. In the older forests, however, these species tended to use other types of nesting sites, except T. unifasciatus, which nested almost exclusively in milkweed stems, independently from the age of forests. In the older forests, more colonies were found in the soil and in decaying wood than in the younger stands. The reason of this may be that during succession, the forest soil becomes firm enough for nest construction (contrary to the sandy soils of younger forests) (BROCKERHOFF et al. 2008), and the number of fallen branches and rotten trees increases, which can serve as suitable nesting sites for many ant species (AlvarAdo et al. 2000, BROCKERHOFF et al. 2008). Our findings support these observations, since we found less species nesting in milkweed stems, and more species that used other types of nesting sites, despite the presence of milkweed stems. Nevertheless, the high abundances of milkweed, especially in the earlier successional stages of the forests, can lead to the significant alteration of local ant assemblages. In the early stages, it can affect the availability of food by hosting several species of aphids, whose honeydew can serve as a stable food source even for laterappearing ant species (Alloway 1979, Stuart 1992, Molnár et al. 2010). More importantly, in the presence of milkweed, the nesting habits of some ants can be altered, since dried milkweed stems can offer nesting possibilities for many 
opportunistic, disturbance tolerant ant species. On the other hand, some species that have more developed habitat requirements (characteristic for later successional stages) can also find suitable nesting sites in the early stages, resulting in the homogenization of local ant assemblages through the different successional stages. The appearance of these species in the early stages in higher abundances due to changes induced by $A$. syriaca in the habitat structure (see e.g. Riley \& Browne 2011) can lead to the competitive exclusion of other, mainly habitat specialist species, leading to a decrease in local species diversity (OKLAND et al. 2003).

In conclusion, with the growing age of the forests, many changes take place that can markedly affect, among others, the nesting habits of ants and thereby influence the composition and structure of their assemblages. Furthermore, the regular disturbance regime of planted forests can promote the appearance and fast spread of invasive plants, such as $A$. syriaca, which can further alter the nesting habits of many ant species by providing potential nesting sites. This can lead to a homogenization of the different aged stands in respect of local ant assemblages, resulting in considerable differences only between the younger and older forests.

$*$

Acknowledgements - We are grateful for the help of Márta Zalatnai and Mária Reszler-Fehér with the coenological record, and for Róbert Gallé, Enikő Német, Attila Torma and two anonymous reviewers for their useful comments and suggestions which greatly improved our manuscript.

\section{REFERENCES}

Abdala-Roberts, L., Mooney, K. A. \& Agrawal, A. A. (2012): Ant-aphid interactions on Asclepias syriaca are mediated by plant genotype and caterpillar damage. - Oikos 121: 1905-1913. https://doi.org/10.1111/j.1600-0706.2012.20600.x

Alloway, T. M. (1979): Raiding behavior of two species of slave-making ants, Harpagoxenus americanus (Emery) and Leptothorax duloticus Wesson (Hymenoptera: Formicidae). - Animal Behavior 27: 202-210. https://doi.org/10.1016/0003-3472(79)90140-4

Alvarado, M., Gallé, L., Kujawa, K. \& Tryjanowski, P. (2000): Ant assemblages associated with lowland forests in the southern part of the Great Hungarian Plain. - Acta Zoologica Academiae Scientiarum Hungaricae, 46: 103-114.

Andersen, A. N. (1991): Parallels between ants and plants: implications for community ecology. Pp. 539-558. In: Huxley, C. R. \& Cutler, D. F. (eds): Ant-plant interactions. Oxford University Press, Oxford, UK.

Andersen, A. N. \& Patel, A. D. (1994): Meat ants as dominant members of Australian ant communities: an experimental test of their influence on the foraging success and forager abundance of other species. - Oecologia 98: 15-24. https://doi.org/10.1007/BF00326085 
BAGI, I. (2008): Common milkweed Asclepias syriaca L. Pp. 151-159. In: Вотta-Dukát, Z. \& BALOGH, L. (eds): The most important invasive plants in Hungary. - Institute of Ecology and Botany, Hungarian Academy of Sciences, Vácrátót.

BAlogh, L., DANCZA, I. \& KirÁly, G. (2007): Preliminary report on the grid-based mapping of invasive plants in Hungary. In: Rabitsch, W., EssL, F. \& Klingenstein, F. (eds): Biological invasions - from ecology to conservation. - Neobiota 7: 105-114.

Bates, D., Maechler, M., Bolker, B. \& Walker, S. (2015): Fitting linear mixed-effects models using lme4. - Journal of Statistical Software 67(1): 1-48. https://doi.org/10.18637/jss. v067.i01

Bhowmik, P. C. \& Bandeen, J. D. (1976): The biology of Canadian weeds. 19. Asclepias syriaca L. - Canadian Journal of Plant Science 56: 579-589.

Bıró, M. (2006): A történeti térképekre alapuló vegetációrekonstrukció és alkalmazásai a DunaTisza közén. [The method of vegetation reconstruction based on historical maps and its application to the area between the Danube and Tisza Rivers.] - PhD thesis, University of Pécs, Hungary. [in Hungarian]

Borhidi, A. (2003): Magyarország növénytársulásai. - Akadémiai Kiadó, Budapest, 610 pp.

BrAsChler, B. \& BAUR, B. (2003): Effects of experimental small-scale grassland fragmentation on spatial distribution, density, and persistence of ant nests. - Ecological Entomology 28: 651-658. https://doi.org/10.1111/j.1365-2311.2003.00549.x

BREMER, L. L. \& FARLEY, K. A. (2010): Does plantation forestry restore biodiversity or create green deserts? A synthesis of the effects of land-use transitions on plant species richness. - Biodiversity and Conservation 19: 3893-3915. https://doi.org/10.1007/s10531-010-9936-4

Brian, M. V., Hibble, J. \& Stradling, D. J. (1965): Ant pattern and density in a southern English heath. - Journal of Animal Ecology 34: 545-555. https://doi.org/10.2307/2448

Brockerhoff, E. G., Berndt, L. A. \& Jactel, H. (2005): Role of exotic pine forests in the conservation of the critically endangered New Zealand ground beetle Holcaspis brevicula (Coleoptera: Carabidae). - New Zealand Journal of Ecology 29(1): 37-43.

Brockerhoff, E. G., Jactel, H., Parotta, J. A., Quine, Ch. P. \& Sayer, J. (2008): Plantation forests and biodiversity: oxymoron or opportunity? - Biodiversity and Conservation 17: 925-951. https://doi.org/10.1007/s10531-008-9380-x

Carnus, J. M., Parotta, J., Brockerhoff, E., Arbez, M., Jactel, H., Kremer, A., Lamb, D., O'HARA, K. \& WALters, B. (2006): Planted forests and biodiversity. - Journal of Forestry 104: 65-77.

Cerdá, X, Retana, J. \& Cros, S. (1997): Thermal disruption of transitive hierarchies in Mediterranean ant communities. - Journal of Animal Ecology 66: 363-374. https://doi. org $/ 10.2307 / 5982$

Cerdá, X., Arnan, X. \& Retana, J. (2013): Is competition a significant hallmark of ant (Hymenoptera: Formicidae) ecology? - Myrmecological News 18: 131-147.

Clark, P. J. \& Evans, F. C. (1954): Distance to nearest neighbor as a measure of spatial relationships in populations. - Ecology 35: 445-453. https://doi.org/10.2307/1931034

Coelno, I. R. \& Riberio, S. P. (2006): Environment heterogeneity and seasonal effects in ground-dwelling ant (Hymenoptera: Formicidae) assemblages in the Parque Estadual do Rio Doce, MG, Brazil. - Neotropical Entomology 35: 19-29. https://doi.org/10.1590/ S1519-566X2006000100004

Connell, J. H. \& Slatyer, R. O. (1977): Mechanisms of succession in natural communities and their role in community stability and organization. - The American Naturalist 111: 1119-1144. https://doi.org/10.1086/283241 
Cushman, J. H., Martinsen, G. D. \& Mazeroll, A. I. (1988): Density and size-dependent spacing of ant nests: evidence for intraspecific competition. - Oecologia 77: 522-525. https://doi.org/10.1007/BF00377268

Czechowski, W. \& Markó, B. (2005): Competition between Formica cinerea Mayr (Hymenoptera: Formicidae) and co-occurring ant species, with special reference to Formica rufa L.: direct and indirect interferences. - Polish Journal of Ecology 53: 467-487.

Czechowski, W., Radchenko, A. \& Czechowska, W. (2002): The ants (Hymenoptera, Formicidae) of Poland. - Museum and Institute of Zoology, Polish Academy Sciences, Warszawa, $200 \mathrm{pp}$.

Czechowski, W., Radchenko, A., Czechowska, W. \& Vepsäläinen, K. (2012): The ants of Poland (with reference to the Myrmecofauna of Europe). - PAN, Warszawska Drukarnia Naukowa, Warszawa, 496 pp.

Davidson, D. W. (1998): Resource discovery versus resource domination in ants: a functional mechanism for breaking the trade-off. - Ecological Entomology 23: 484-490. https://doi.org/10.1046/j.1365-2311.1998.00145.x

Doncaster, C. P. (1981): The spatial distribution of ants' nests on Ramsey Island, South Wales. - Journal of Animal Ecology 50: 195-218. https://doi.org/10.2307/4040

GALLÉ, L. (1991): Structure and succession of ant assemblages in a north European sand dune area. - Holartic Ecology 14: 31-37. https://doi.org/10.1111/j.1600-0587.1991.tb00630.x

Gallé, L., Hornung, E. \& Kerekes, J. (1998): Structure of ant assemblages in a MiddleEuropean successional sand-dune area. - Tiscia 31: 19-28.

Gallé, R., Erdélyi, N., Szpisják, N., Tölgyesi, Cs. \& MaÁk, I. (2015): The effect of the invasive Asclepias syriaca on the ground-dwelling arthropod fauna (Araneae, Formicidae, Diplopoda). - Biologia 70: 104-112. https://doi.org/10.1515/biolog-2015-0011

Gallé, R., Torma, A. \& MAÁк, I. (2016): The effect of forest age and habitat structure on the ground-dwelling ant assemblages of lowland poplar plantations. - Agricultural and Forest Entomology 18:151-156. https://doi.org/10.1111/afe.12148

Gordon, D. R. (1998): Effects of invasive, non-indigenous plant species on ecosystem processes: lessons from Florida. - Ecological Applications 84: 975-989. https://doi. org/10.1890/1051-0761(1998)008[0975:EOINIP]2.0.CO;2

Gotelli, N. J. \& Ellison, A. M. (2002): Assembly rules for New England ant assemblages. - Oikos 99: 591-599. https://doi.org/10.1034/j.1600-0706.2002.11734.x

Hejda, M., Petr, P. \& Jarošík, V. (2009): Impact of invasive plants on the species richness, diversity and composition of invaded communities. - Journal of Ecology 97: 393-403. https://doi.org/10.1111/j.1365-2745.2009.01480.x

Herbers, J. M. (1989): Community structure in north temperate ants: temporal and spatial variation. - Oecologia 81: 201-211. https://doi.org/10.1007/BF00379807

Hoffman, B. D. \& Andersen, A. N. (2003): Responses of ants to disturbance in Australia, with particular reference to functional groups. - Austral Ecology 28: 444-464. https:// doi.org/10.1046/j.1442-9993.2003.01301.x

Holec, M., Frouz, J. \& Рокоrnŷ, R. (2006): The influence of different vegetation patches on the spatial distribution of nests and the epigeic activity of ants (Lasius niger) on a spoil dump after brown coal mining (Czech Republic). - European Journal of Soil Biology 42: 158-165. https://doi.org/10.1016/j.ejsobi.2005.12.005

Hölldobler, B. \& Wilson, E. O. (1990): The ants. - The Belknap Press of Harvard University Press, Cambridge, 732 pp. https://doi.org/10.1007/978-3-662-10306-7

Kertész, M., Kelemen, E., Biró, M., Kovács-Láng, E. \& Kröel-Dulay, Gy. (2011): Az ökoszisztéma szolgáltatások és a zavarási rezsim, mint természet-társadalom kapcsolat 
a Kiskunsági-homokhátságon. (Description of ecosystem services and disturbance regime as connection between environment and society - summary). Pp. 91-110. In: NAGY, G. (ed.): Az ökoszisztéma szolgáltatások hazai eredményeinek összegzése, lehetséges továbblépések megvitatása. - MTA TAKI - CEU, Budapest.

Levings, S. C. \& Traniello, J. F. A. (1981): Territoriality, nest dispersion, and community structure in ants. - Psyche 88: 265-319. https://doi.org/10.1155/1981/20795

LốrINCZI, G. (2011): Density and spatial pattern of nests in sub-Mediterranean grounddwelling ant communities (Hymenoptera: Formicidae). - Community Ecology 12: 51-57. https://doi.org/10.1556/ComEc.12.2011.1.7

Molnár, N., Harkai, A. \& Setényi, R. (2010): Spatial patterns of Aphis gossypii (Sternorrhyncha: Aphididae) populations feeding on milkweed (Asclepias syriaca). - Acta Phytopathologica et Entomologica Hungarica 45: 71-80. https://doi.org/10.1556/APhyt.45.2010.1.4

Noble, I. R. \& Dirzo, R. (1997): Forests as human-dominated ecosystems. - Science 277: 522-525. https://doi.org/10.1126/science.277.5325.522

Okland, T., Rydgren, K., Okland, R. H., Storaunet, K. O. \& Rolstad J. (2003): Variation in environmental conditions, understory species number, abundance and composition among natural and managed Picea abies forest stands. - Forest Ecology and Management 177: 17-37. https://doi.org/10.1016/S0378-1127(02)00331-6

Osorio-Perez, K., Barbena-Arias, M. F. \& Aide, T. M. (2007): Changes in ant species richness and composition during plant secondary succession in Puerto Rico. - Caribbean Journal of Science 43: 244-253. https://doi.org/10.18475/cjos.v43i2.a9

Punttila, P. \& Haila, Y. (1996): Colonisation of a burned forest by ants in the southern Finnish boreal forest. - Silva Fennica 30: 421-435. https://doi.org/10.14214/sf.a8502

R Development Core Team (2014): R. A language and environment for statistical computing. R Foundation for Statistical Computing, Vienna, http://www.R-project.org/

RÉDEI, K. (1994): Ígéretes fehér nyár (Populus alba L.) származások fatermése a Duna-Tisza közi homokháton. (Yield of promising Populus alba proveniences on the DanubeTisza region sands.) - Erdészeti Kutatások 84: 81-90.

Ribas, C. R., Campos, R. B., Sсhмidt, F. A. \& Solar, R. R. (2012): Ants as indicators in Brazil: a review with suggestions to improve the use of ants in environmental monitoring programs. - Psyche: A Journal of Entomology 2012: 636749. https://doi. org/10.1155/2012/636749

Riley, K. N. \& Browne, R. A. (2011): Changes in ground beetle diversity and community composition in age structured forests (Coleoptera, Carabidae). - ZooKeys 147: 601621. https://doi.org/10.3897/zookeys.147.2102

Ryti, R. T. \& CAsE, T. J. (1984): Spatial arrangement and diet overlap between colonies of desert ants. - Oecologia 62(3): 401-404. https://doi.org/10.1007/BF00384274

Ryti, R. T. \& CASE, T. J. (1986): Overdispersion of ant colonies: a test of hypotheses. - Oecologia 69: 446-453. https://doi.org/10.1007/BF00377067

SANDERS, N. J. \& Gordon, D. M (2000): The effects of interspecific interactions on resource use and behavior in a desert ant. - Oecologia 125: 436-443. https://doi.org/10.1007/ s004420000463

SAvolainen, R. \& VepsäläInen, K. (1988): A competition hierarchy among boreal ants: impact on resource partitioning and community structure. - Oikos 51: 135-155. https:// doi.org/10.2307/3565636

Schirmel, J., Timler, L. \& Buchiolz, S. (2011): Impact of the invasive moss Campylopus introflexus on carabid beetles (Coleoptera: Carabidae) and spiders (Araneae) in acidic coastal dunes at the southern Baltic Sea. - Biological Invasions 13: 605-620. https://doi. org/10.1007/s10530-010-9852-2 
Smith, R. A., Mooney, K. A. \& Agrawal, A. A. (2008) Coexistence of three specialist aphids on common milkweed, Asclepias syriaca. - Ecology 89(8): 2187-2196. https://doi. org/10.1890/07-1441.1

SoAres, S. M. \& SCHOEREder, J. H. (2001): Ant-nest distribution in a remnant of tropical rainforest in southeastern Brazil. - Insectes Sociaux 48: 280-286. https://doi.org/10.1007/ PL00001778

SoAREs, S. D. A. (2013): The role of competition in structuring ant communities: A review. - Oecologia Australis 17: 81-91. https://doi.org/10.4257/oeco.2013.1702.08

StuART, R. J. (1992): Nestmate recognition and the ontogeny of acceptability in the ant Leptothorax curvispinosus. - Behavioral Ecology and Sociobiology 30: 403-408. https://doi. org/10.1007/BF00176175

Töröк, K., Halassy, M. \& Szabó, R. (2003): Restoration strategy for endemic grasslands in a low productive region of Hungary. Pp. 1132-1138. In: Allsopp, N., Palmer, A. R., Milton, S. J., Kirkman, P., Kerley, G. I. H., Hurt, C. R. \& Brown, C. J. (eds): Proceedings of the VIIth International Rangelands Congress. - Durban, South Africa.

Traniello, J. F. A. \& Levings, S. C. (1986): Intra- and intercolony patterns of nest dispersion in the ant Lasius neoniger: correlations with territoriality and foraging ecology. - Oecologia 69: 413-419. https://doi.org/10.1007/BF00377064

Vepsäläinen, K., SAvolainen, R., Tiainen, J. \& Vilén, J. (2000): Successional changes of ant assemblages: from virgin and ditched bogs to forests. - Annales Zoologici 37: 135-149.

Received October 2, 2015, accepted March 6, 2017, published October 20, 2017 


\section{A Magyar Természettudományi Múzeum gyászbogártípusainak (Tenebrionidae) katalógusa \\ Type catalogue of darkling beetles (Tenebrionidae) preserved in the Hungarian Natural History Museum}

by Ottó MerkL, Aranka Grabant \& Zoltán SoltésZ

The Hungarian Natural History Museum (HNHM) houses one of the largest and most complete Tenebrionidae collections of the world, thanks to Zoltán Kaszab (1915-1986), the Museum's former General Director and the most prominent figure of Hungarian coleopterology. The book is a commemoration of the centenary of his birthday.

The introduction summarises the history of the Hungarian Natural History Museum, its Coleoptera Collection and the scientific activity of Zoltán Kaszab.

Type specimens constitute the scientifically most valuable assets of the collection. The catalogue contains types of all the species, subspecies, variations and aberrations which have ever been described in the family Tenebrioni-

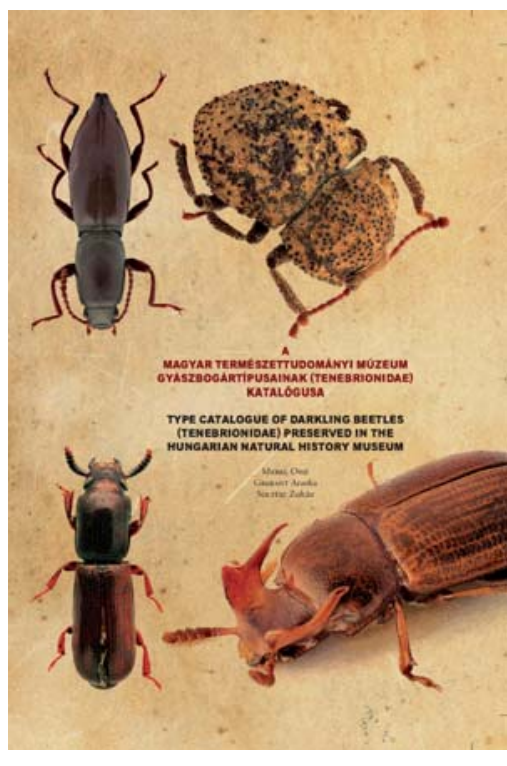
dae, and kept in the HNHM, including those already assigned to other families, as well as those which were described in different families but are now members of Tenebrionidae. A total of 21,313 type specimens belonging to 5,941 names are listed herein, including 1,222 holotypes, 4 neotypes, 88 lectotypes, 4,914 syntypes, 86 allotypes, 248 paralectotypes and 14,751 paratypes. The list of the names is followed by a complete list of the 1,212 publications containing the original descriptions.

Merki, O., Grabant A. \& Soltész Z. (2015): A Magyar Természettudományi Múzeum gyászbogártípusainak (Tenebrionidae) katalógusa. Type catalogue of darkling beetles (Tenebrionidae) preserved in the Hungarian Natural History Museum. - Hungarian Natural History Museum, Budapest, 735 pp.

ISBN 9789639877238 [hardcover]

Orders should be sent to:

The Library, Hungarian Natural History Museum

H-1083 Budapest, Ludovika tér 2, Hungary

Fax: (36-1) 3172320, e-mail: angela@nhmus.hu 